\begin{tabular}{ll|l|}
\hline Gazi & $\begin{array}{l}\text { GAZi iKTiSAT VE ișleTME DERGisi } \\
\text { GAZi JOURNAL OF ECONOMICS \& BUSINESS }\end{array}$ & Giid \\
\hline $\begin{array}{l}\text { AKADEMIK } \\
\text { YAYINCILIK }\end{array}$ & & \\
\hline
\end{tabular}

\title{
The impact of intellectual capital on firm performance and value: An application of MVAIC on firms listed in Borsa Istanbul
}

\author{
Asli Aybars ${ }^{a^{*}}$, Mehtap Öner ${ }^{\text {b }}$ \\ a Assoc. Prof. Dr., Marmara University, Business Administration Faculty, Department of Business Administration, Kadlköy, \\ Istanbul 34722, TURKEY. E-mail: asli.aybars@ marmara.edu.tr. ORCID ID: https://orcid.org/0000-0002-7899-2367 \\ ${ }^{b}$ Assist. Prof. Dr., Marmara University, Business Administration Faculty, Department of Business Administration, Kadıköy, \\ Istanbul 34722, TURKEY. E-mail: mehtap.oner@marmara.edu.tr.ORCID ID: https://orcid.org/0000-0001-7527-5875
}

\section{ARTICLE INFO \\ Received: 07.05.2021 Accepted: 26.01.2022 Available online: 18.02 .2022 Article type: Research article}

Keywords:

Intellectual capital, MVAIC, firm performance, firm value, panel data analysis

\begin{abstract}
This paper attempts to evaluate the impact of intellectual capital (IC) and its components on financial performance and value of listed companies operating in Turkish manufacturing industry. Accordingly; using panel data methodology, this study incorporates data of 75 companies listed in Borsa Istanbul (BIST) and data was extracted from Thomsen Reuters Database and Public Disclosure Platform with a total of 825 firm-year observations for the period between 2009 and 2019, inclusive. The Modified Value Added Intellectual Coefficient (MVAIC) is employed to capture IC efficiency together with its components, namely; Human Capital Efficiency (HCE), Structural Capital Efficiency (SCE), Relational Capital Efficiency (RCE), and Capital Employed Efficiency (CEE). The findings fail to provide a significant influence of MVAIC on the selected performance measures. However, as far as additional analysis utilizing the components is concerned, the only contributor to both firm financial performance and value is documented to be CEE while $\mathrm{HCE}, \mathrm{SCE}$, and RCE are found to exert no significant impact.
\end{abstract}

\section{Entelektüel sermayenin firma performansı ve değeri üzerindeki etkisi: Borsa İstanbul'da listelenen firmalar için MVAIC uygulaması}

\author{
MAKALE BÍLGISİ \\ Geliș tarihi: 07.05.2021 \\ Kabul tarihi: 26.01.2022 \\ Çevrimiçi kullanım \\ tarihi: 18.02 .2022 \\ Makale Türü: Araştırma \\ makalesi
}

öz

\begin{abstract}
$\mathrm{Bu}$ çalışma ile entelektüel sermaye ve bileşenlerinin Türk imalat sanayinde faaliyet gösteren halka açık firmaların finansal performansı ve firma değeri üzerindeki etkisini ortaya koymak hedeflenmiştir. Bu amaçla Borsa İstanbul'da (BIST) 2009 - 2019 yılları arasında işlem gören 75 halka açık firmaya ait veriler, Kamuyu Aydınlatma Platformu
\end{abstract}

\footnotetext{
* Corresponding Author

Doi: https://doi.org/10.30855/gjeb.2022.8.1.004
} 
ve Thomsen Reuters veri tabanlarından alınarak toplam 825 gözleme dayanan panel veri analizi gerçekleştirilmiştir. Entelektüel sermaye etkinliğini ölçmek için Değiştirilmiş Entelektüel Katma Değer Katsayısı (MVAIC) kullanılırken, bileşenlerinin etkinliğini tespit etmek için Beşerî Sermaye Etkinliği (HCE), Yapısal Sermaye Etkinliği (SCE), İlişkisel Sermaye Etkinliği (RCE) ve Kullanılan Sermaye Etkinliği (CEE) kullanılmıştır. Çalışmanın bulguları entelektüel sermayenin seçili performans göstergeleri üzerinde anlamlı bir etkisinin olmadığını göstermiştir. Entelektüel sermaye bileşenleri için yapılan ek analiz sonucuna göre ise sadece Kullanılan Sermaye Etkinliğinin firma karlılığı ve değeri üzerinde pozitif etkisinin olduğu tespit edilmiştir.

\section{Introduction}

Intellectual capital (IC) has been regarded as a crucial factor of competitive advantage and sustainable success for corporations in the last decades. Accordingly, the topic has attracted the attention of both practitioners and academicians to reveal and quantify its impact on firms' financial and market performance. The fast changing world has increased the importance of knowledge accumulation and technological advancements for prosperity and success in competitive environments; thus, both tangible and intangible resources have attained greater strategic importance. With the emergence of the knowledge-based economies, intangible assets' influence on corporate success besides the already established role of tangibles has gained utter importance. As also supported by the Organization for Economic Co-operation and Development (OECD, 2006), economic value of the firm relies not only on the generation and accumulation of tangible assets but also on production and use of human capital and knowledge. Edvinsson and Malone (1997, p. 44) explain IC, which comprises intangible resources, as 'the possession of knowledge, applied experience, organizational technology, customer relationships and professional skills that provide the firm with a competitive edge in the market'. Accordingly, IC is regarded as the difference between how investors evaluate the firm versus actual balance sheet values. This definition that considers IC to be made up of only intangible assets of the firms is further supported by Stewart (1997), Roos and Roos (1997), and Bontis, Keow, and Richardson (2000).

Even though no universal definition has been put forth for IC, what is common in most definitions is the concept's being non-physical and intangible in nature, having crucial importance in generating value and attaining sustainable competitive advantage. Accordingly, traditional accounting methods have proven to be insufficient for IC measurement. However; to quantify IC of the firm, various methods have been developed by academicians and practitioners, some of which can be named as Skandia IC Report Method generated by Edvinsson and Malone (1997), Value Added Intellectual Coefficient (VAIC ${ }^{\mathrm{TM}}$ ) model put forth by Pulic (2000), and Intangible Asset Monitor Approach of Sveiby (1997). As seen in literature, VAIC ${ }^{\mathrm{TM}}$ is the most widely used model in prior empirical works to proxy for IC (Firer and Williams, 2003; Zeghal and Maaloul, 2010; Dzenopoljac, Yaacoub, Elkanj, and Bontis, 2017) due to its simplicity, ability to enable cross-firm and cross-country comparisons, and being easily computed from audited publicly available financial statements.

Despite its common use, VAIC ${ }^{\mathrm{TM}}$, which comprises Human Capital Efficiency (HCE), Structural Capital Efficiency (SCE), and Capital Employed Efficiency (CEE) coefficients as three key components is not free from criticisms. As stated by Dzenopoljac et al. (2017), the model utilizes the historical data in financial statements; thus, it demonstrates deficiencies to stand for a measure that provides a feature for future value creation. Also, the model is criticized for its measuring only the operating performance of the firm since it can be derived from financial statements. The majority of the remaining criticisms have been generally directed towards the components of VAIC ${ }^{\mathrm{TM}}$ model such that human capital (HC) focuses only on salary and other employee related costs not taking into account expenses related with employee training. Iazzolina and Laise (2013) criticize Pulic stating that $\mathrm{HC}$ in his model is only an income statement-based measure; however, the concept is more comprehensive than a single accounting term since it encompasses elements as employee training, motivation, skills, and experiences. Stahle, Stahle, and Aho et al. (2011) criticize VAIC ${ }^{\mathrm{TM}}$ on the 
grounds that it measures the firms' labor and capital efficiency rather than IC as a total. They also state that a perfect superimposition problem exists between the formula for SCE and HCE since they are computed as derivatives of each other. Further criticism is directed towards structural capital (SC) in that its computation confuses the use of capitalized and cash flow entities since these two categories act differently in fundamental ways. In a prior study, Andriessen $(2004$, p. 368) emphasizes this issue stating that even though SC is a stock entity, it is computed under VAIC ${ }^{\mathrm{TM}}$ as a residual of two flows; namely, value added and human capital. Lastly, although the intangibles of the firm such as human, structural, and relational capital, are the major drivers of IC accumulation, VAIC ${ }^{\mathrm{TM}}$ model does not include relational capital, which results in misleading calculations (Nimtrakoon, 2015; Stahle et al. 2011).

Numerous researchers have attempted to extend and modify VAIC ${ }^{\mathrm{TM}}$ model due to the above stated limitations and criticisms (Nazari and Herremans, 2007; Vishnu and Gupta, 2014). Accordingly, this study utilizes the Modified Value Added Intellectual Coefficient (MVAIC) model as an indicator that comprises physical, human, structural, and relational capital components; thus, increasing the explanatory power of the individual components (Nimtrakoon, 2015; Ulum, Kharismawati, and Syam, 2017; Buallay, Cummings, and Hamdan, 2019; Xu and Wang, 2019; Yao, Haris, Tariq, Javaid, and Khan, 2019; Tiwari, 2020; Xu and Li, 2020). Therefore, this paper is concerned with the evaluation of the link between IC efficiency and financial performance quantified by an accounting-based performance measure, ROA; and the link between IC efficiency and firm value quantified by a market-based performance measure, Tobin's Q, for the Turkish manufacturing listed companies on Borsa Istanbul (BIST) between the years 2009 and 2019.

The contributions of this study to IC literature can be summarized in three aspects. Firstly, a comprehensive review demonstrates that the majority of the empirical researches in this array of literature use VAIC ${ }^{\mathrm{TM}}$ (Pulic, 2000, 2004) as an aggregate measure of firm IC. Accordingly relational capital, has been incorporated into Pulic's VAIC ${ }^{\mathrm{TM}}$ model as an additional variable in line with the above stated researches to result in MVAIC in the current study; thereby, modifying the model to possess more explanatory power on the selected performance measures. As far as the literature review is concerned, studies with Turkish stock market data fail to utilize the modified model; thus, this study is one of the pioneering studies conducted on the Turkish market using MVAIC as a proxy for IC. Thus, it attempts to fill a gap by investigating the influence of IC and its components on firm performance and value in a developing market. Second, as it might prove to be inadequate to use a single indicator of performance for a thorough stakeholder evaluation, the current study investigates performance from two perspectives in that it utilizes measures that are both accounting and marketbased. Lastly, this study uses a relatively long data set in the Turkish market that may reveal the importance of knowledge-based asset accumulation.

The rest of the paper is as follows. The next section provides information as to the intellectual capital components followed by Section 3 revealing the literature review on the relationship between MVAIC and firm performance. Section 4 is dedicated to hypotheses development. Section 5 provides the methodology together with the data, variable definitions, and the models utilized. Empirical results are revealed in Section 6. Lastly, related concluding remarks are put forth in Section 7.

\section{Intellectual capital components}

The concept of IC, that has been firstly referred by John Kenneth Galbraith in late 1960s, is classified generally into three major components named as human, structural, and relational capital (Bontis, 1998; Sveiby, 1997; Stewart, 1997).

Human capital encompasses employees' knowledge, skills, competencies, experience, and individual values (Edvinsson and Malone, 1997). As all these features are unique to individuals, organizations may be threatened on the condition that employees leave the company, which may result in corporate memory loss. Further, Sveiby (1997) emphasizes the importance of human resources as one of the main sources for the company intangibles contributing to the firms' IC accumulation.

Structural capital, which is another component that is accumulated within the organization adding to the IC of the firm, consists of trademarks, copyrights, and patents generated by the innovative 
capacity of the firm through R\&D investments. Additionally; databases, administrative systems, structures, strategies, and culture in an organization are also other important drivers of structural capital. Apart from these issues, distribution networks and supply chains further contribute to this component (Sveiby, 1997; Bontis, et al., 2000; Petty and Gurherie, 2000). The common feature for all these capabilities that make up the structural capital is that they are inseparable from the organization (Joshi, Cahill, Sidhu, and Kansal, 2013).

When compared to the other two components, relational capital is regarded to be more externally oriented since it is accumulated via the company's interaction with outside parties. Thus, this component is made up of intellectual assets attained through the interrelationships with competitors, customers, suppliers, distributors, government or any other group that the firm interacts with (Bontis et al. 2000). With the help of these relations, firm's ability to generate customer satisfaction, brand image and loyalty, collaborations, and agreements with other businesses increases (Mohammad and Bujang, 2019). Knowledge developed not only through external parties but also interactions within the company also adds to this component's accumulation. Johnson (1999) further emphasizes the importance of this component in improving human and structural capital within the firm. As a result, firms can achieve value creation through the combination of external relationships with internal intellectual resources.

\section{Literature review}

As will be revealed in this section, most of the prior empirical evidence in this array of literature demonstrates the positive impact of IC on firms' financial and market performance. Additionally, further analyses with respect to the MVAIC components provide different findings as to the direction and level of the impact. The differences in the results are adhered to country, industry, and firmspecific factors together with the period of the analyses and computational differences.

A study performed on the ASEAN stock exchange listed companies in technology sector examines the influence of IC on firms' both financial and market performance. Even though the findings reveal no significant difference in MVAIC across countries, IC components are found to exert different degrees of significant impact on the selected performance measures for each country. While market value and performance measures are documented to be positively linked with IC, the most significant components are determined to be capital employed and human capital efficiency (Nimtrakoon, 2015). Results provided by Ulum et al. (2017) on the Indonesian 50 biggest market capitalization listed companies also support the positive influence of MVAIC on different corporate financial performance measures between the years 2007-2014. Further evidence for the positive impact of IC on both firm financial and market performance for South Asian companies is provided by Restuti, Diyanty, and Shauki, (2018). Additionally, component-wise analysis shows that HCE contributes to both performance measures, whereas CEE is influential on financial performance only. In addition to these findings, SCE and RCE are found to exert no influence on the selected measures.

Buallay et al. (2019) utilize data belonging to economies in Gulf Cooperation Council to evaluate the impact of IC on Islamic and conventional banks. The overall findings show the positive influence of MVAIC on financial and market performance for Islamic banks while that is proved for the operational and financial performance of conventional banks. The component wise findings for Islamic banks reveal that while HCE and CEE contribute to financial and operational performance, HCE and RCE add to market performance. On the other hand, the results for conventional banks show that HCE and CEE influence operational performance; whereas, SCE and CEE drive financial performance. Furthermore, market performance is found to be affected by only RCE. In another study, Buallay (2019) indicates the presence of the positive contribution of MVAIC on financial and market performance for only Islamic banks in Gulf Countries; while the positive influence exists for operational and financial performance for only conventional banks. The findings for the subcomponents differ according to the type of the bank such that HCE and CEE are found to affect the financial and operational performance of Islamic banks, while they only contribute to operational performance of conventional banks. Furthermore, whereas market performance is improved by HCE and RCE for Islamic banks, it is positively affected by only RCE for conventional banks. Additionally, SCE and CEE components drive financial performance for conventional banks (Buallay, 2019). 
Further empirical evidence from Malaysian finance sector supports the contribution of IC on financial performance. Furthermore, this positive contribution is also exerted by the components; namely, CEE, HCE, and SCE. However, RCE is not determined to be a significant driver of financial performance (Mohammad and Bujang, 2019). The evidence for Pakistani financial institutions demonstrates the positive impact of IC, proxied by both VAIC and MVAIC; on profitability and productivity with human capital being the most influential component (Yao et al. 2019). The empirical findings on the healthcare industry of India also show that IC proxied by VAIC and MVAIC has positive association with firm profitability. However, the only component that is found to impact profitability is reported to be CEE (Tiwari, 2020).

The study of Xu and Wang (2019) provide supporting evidence for contribution of IC measured by both VAIC and MVAIC for the Chinese and South Korean textile industry. The overall findings prove the positive and significant impact of IC on the selected performance measures. The findings as to subcomponents in terms of the degrees of positive influence can be sequenced as that of CEE followed by SCE and RCE for China. Korean results demonstrate a relatively low contribution by RCE; whereas, the contribution is more in terms of CEE and HCE. Another comprehensive study using dataset made up of 953 listed companies on the Shanghai and Shenzhen Stock Exchanges also documents the positive influence of MVAIC on indicators of firm performance. At component level analysis, findings reveal CEE as the most important contributor to performance without regard to the type of company ownership, industry or region. Additionally, IC exerts more influence on performance of state owned enterprises in comparison to private ones. Lastly, the impact of IC is more strongly pronounced for high-tech companies ( $\mathrm{Xu}$ and $\mathrm{Li}, 2020$ ).

Another study conducted on Indonesian listed companies shows that while IC positively contributes to firm performance in both high and low-level knowledge industries, it is found to have no significant influence on the firms' market value (Soetanta and Liem, 2019). Further analysis on data belonging to high-tech and non-high-tech small and medium sized enterprises listed on Shenzhen stock exchange demonstrates that MVAIC is a positive driver of performance regardless of firm type with HCE, SCE, and CEE having more influence in comparison to RCE (Xu and $\mathrm{Li}, 2019$ ).

During the literature review, it has been observed that there is only one study using MVAIC as the explanatory variable in exploring the impact of IC on financial performance and firm value for publicly listed firms in Turkey. Using a dataset of 49 companies for the period between 2011 and 2014, models that utilize MVAIC components are found to be more successful in explaining the above stated relationship with physical and human capital contributing to financial performance, and physical and relational capital to market performance (Y1lmaz and Acar, 2018).

In line with the prior empirical literature summarized above, this study addresses the main research question of whether IC is influential on financial performance and firm value of listed Turkish manufacturing firms. Furthermore; as the component wise literature review documents controversial results in different markets, the research question is extended to include the individual impact of components as well.

\section{Hypothesis development}

The rationality to explore the nexus between IC and performance rests upon the resource-based view (RBV) of the firm that defines tangible and intangible assets as strategic assets enabling the firm to gain competitive advantage and display superior performance (Wernerfelt, 1984). Furthermore, Barney (1991) states that for a resource to be heterogeneous and immobile; thus, generate sustainable competitive advantage, it has to have four attributes, namely; value, rareness, imperfect imitability, and nonsubstitutability (Barney, 1991). Literature defines IC as a major strategic resource that is utilized by the firm being critical to attain competitive advantage and improve its performance by value creation (Stewart, 1997; Clarke, Seng, and Whitting, 2011). Numerous studies in literature have supported this positive association between IC and performance (Xu and Li, 2020, Buallay, 2019, Restuti et al. 2018, Nimtrakoon, 2015). Accordingly, the below alternative hypotheses have been formulated:

1) $\mathrm{H}_{1}$ : IC will be positively related with firm financial performance 
2) $\mathrm{H}_{1}$ : IC will be positively related with firm value

In accordance with prior empirical studies that hypothesize the potential positive influence of IC on firm financial performance and market value, IC components are also investigated to evaluate their influence on performance measures. However; numerous studies, which investigated each components' effect on performance, reached mixed results as to the components' varying impacts (Xu and Wang, 2019; Nimtrakoon, 2015; Clarke et al. 2011; Zeghal and Maaloul, 2010; Firer and Williams, 2003). Therefore, the below alternative hypotheses are generated to evaluate componentwise influence on selected performance measures:

3) $\mathrm{H}_{1}$ : CEE will be positively related with firm financial performance

4) $\mathrm{H}_{1}: \mathrm{HCE}$ will be positively related with firm financial performance

5) $\mathrm{H}_{1}$ : SCE will be positively related with firm financial performance

6) $\mathrm{H}_{1}$ : RCE will be positively related with firm financial performance

7) $\mathrm{H}_{1}$ : CEE will be positively related with firm value

8) $\mathrm{H}_{1}$ : HCE will be positively related with firm value

9) $\mathrm{H}_{1}$ : SCE will be positively related with firm value

10) $\mathrm{H}_{1}$ : RCE will be positively related with firm value

\section{Methodology and analysis}

\subsection{The dataset and variables}

The dataset of this paper comprises nonfinancial manufacturing firms listed on BIST in the period between 2009 and 2019, inclusive, extracted from Thomsen Reuters data base and Public Disclosure Platform (KAP). Accordingly, the nexus between IC accumulation and performance is analyzed on a wide dataset from an emerging market made up of 825 firm-year observations adding to the uniqueness of the study. The final dataset, from which companies without sufficient information is omitted, is strongly balanced.

The association between IC and performance is evaluated with a perspective on both financial and market-based performance measures that act as the dependent variables of the models. Whereas ROA is the proxy for financial performance, Tobin's Q stands for market-based performance. In line with the prior studies, ROA is calculated as net income to total assets (Xu and Li, 2020; Buallay, 2019; Buallay et al., 2019; Soetanto and Liem, 2019; Yao et al., 2019; Xu and Wang, 2019; Xu and Li, 2019; Restuti et al., 2018; Maditinos, Chatzoudes, Tsairidis, and Theriou, 2011; Firer and Williams, 2003). Furthermore, Tobin's Q is calculated as the sum of the market value of equity and book value of shortterm liabilities divided into the book value of total assets. This approximate measure of Tobin's $Q$ is in line with the works of Buallay et al. (2019) and Buallay (2019).

Factors other than IC can potentially influence the selected performance measures; thus, in accordance with literature selected control variables are incorporated into the models. To control for the effect of firm size, natural logarithm of total assets (SIZE) is utilized (Soento and Liem, 2019; Restuti et al., 2018; Tran and Vo, 2018; Zeghal and Maaloul, 2010). The possible impact of capital structure on performance is evaluated by adding leverage, computed by the ratio of total debt to total assets (LEV) into the models (Xu and Li, 2020; Dzenopoljac et al., 2016; Firer and Williams, 2003). As stated in the work of Nimtrakoon (2015), the ability of firms to convert HC to SC is greater for more established firms. Thus, the experience and expertise firms have accumulated in their array of business is controlled by the age of the firm (AGE), calculated as the number of years that has passed since the day of incorporation (Yao et al., 2019; Nimtrakoon, 2015).

The explanatory variable to quantify intellectual capital is chosen to be MVAIC in this study. Taking into account the limitations of the VAIC ${ }^{\mathrm{TM}}$ model stated above, the original model developed by Pulic $(2000,2004)$ has been extended and modified (Vishnu and Gupta, 2014; Nimtrakoon, 2015; Ulum et al. 2017; Yao et al. 2019; Xu and Li, 2020). This comprehensive model is generated by 
adding a new variable named as relational capital standing for marketing and selling expenses, to the original VAIC ${ }^{\mathrm{TM}}$ model. As stated in the work of Nazari (2010), these expenses are crucial in that they are undertaken to generate and maintain relationships not only with customers but also a variety of external stakeholders.

This study utilizes MVAIC to quantify IC. In line with VAIC ${ }^{\mathrm{TM}}$ methodology, the value added (VA) of the firm is estimated as an initial step since this variable is an important indicator of business success generated by the firm's overall resources (Pulic, 2000, 2004). VA is calculated as the difference between output and input as;

$$
\mathrm{VA}=\mathrm{OUT}-\mathrm{IN}
$$

where VA is the value added of firm, OUT is the total revenue of firm, and IN is the cost of bought-in materials, components and services of firm. However, depending on the works of Yao et al. (2019), Bontis, Janosevic, and Dzenopoljac (2015), and Pulic (2004), VA is calculated as follows;

$$
\mathrm{VA}=\mathrm{OP}+\mathrm{HC}+\mathrm{D}+\mathrm{A}
$$

where OP stands for operating profit, $\mathrm{HC}$ represents employee salaries and benefit expenses, D and A are proxies for depreciation and amortization expenses, respectively.

After VA is calculated, the following step is to quantify intellectual capital efficiency (ICE) that comprises human capital efficiency (HCE), structural capital efficiency (SCE), and relational capital efficiency (RCE) shown as;

$$
\mathrm{ICE}=\mathrm{HCE}+\mathrm{SCE}+\mathrm{RCE}
$$

with the individual components calculated as follows;

$$
\begin{aligned}
\mathrm{HCE} & =\mathrm{VA} / \mathrm{HC} \\
\mathrm{SCE} & =\mathrm{SC} / \mathrm{VA} \\
\mathrm{RCE} & =\mathrm{RC} / \mathrm{VA}
\end{aligned}
$$

where SC represents structural capital that is computed as the difference between VA and HC, RC is marketing and selling expenses.

As the next step, capital employed efficiency (CEE), which is an indicator of the value created per dollar of capital employed, is calculated as below;

$$
\mathrm{CEE}=\mathrm{VA} / \mathrm{CE}
$$

where CE stands for capital employed computed as book value of total assets. Accordingly, MVAIC that proxies for corporate value creation efficiency is defined as below;

$$
\mathrm{MVAIC}=\mathrm{ICE}+\mathrm{CEE}
$$

or expressed otherwise as;

$$
\mathrm{MVAIC}=\mathrm{HCE}+\mathrm{SCE}+\mathrm{RCE}+\mathrm{CEE}
$$

All the variables utilized are displayed on Table 1 together with their abbreviations and definitions, below. 
Table 1

The variables, abbreviations, and definitions

\begin{tabular}{|c|c|c|}
\hline Variable & Abbreviation & Definition \\
\hline \multicolumn{3}{|l|}{ Dependent Variables } \\
\hline ROA & Return on Assets & Net income / total assets \\
\hline TOBINSQ & Tobin's Q & $\begin{array}{l}\text { (Market value of equity }+ \text { book value of short- } \\
\text { term liabilities) / Book value of total assets }\end{array}$ \\
\hline \multicolumn{3}{|l|}{$\begin{array}{l}\text { Explanatory Variable } \\
\text { (MVAIC Computation) }\end{array}$} \\
\hline Value added & VA & $\mathrm{OP}+\mathrm{HC}+\mathrm{D}+\mathrm{A}$ \\
\hline Operating profit & OP & Operating profit \\
\hline Employee cost & $\mathrm{HC}$ & Employee salaries and benefits expenses \\
\hline Depreciation expense & $\mathrm{D}$ & Depreciation expense \\
\hline Amortization expense & A & Amortization expense \\
\hline $\begin{array}{l}\text { Modified value-added } \\
\text { intellectual coefficient }\end{array}$ & MVAIC & $\mathrm{MVAIC}=\mathrm{HCE}+\mathrm{SCE}+\mathrm{RCE}+\mathrm{CEE}$ \\
\hline Human capital efficiency & HCE & $\mathrm{VA} / \mathrm{HC}$ \\
\hline Structural capital efficiency & SCE & $\mathrm{SC} / \mathrm{VA}$ \\
\hline $\begin{array}{l}\text { Relational capital } \\
\text { efficiency }\end{array}$ & $\mathrm{RCE}$ & $\mathrm{RC} / \mathrm{VA}$ \\
\hline $\begin{array}{l}\text { Capital employed } \\
\text { efficiency }\end{array}$ & CEE & $\mathrm{VA} / \mathrm{CE}$ \\
\hline $\begin{array}{l}\text { Intellectual capital } \\
\text { efficiency }\end{array}$ & ICE & $\mathrm{HCE}+\mathrm{SCE}$ \\
\hline Structural capital & $\mathrm{SC}$ & $\mathrm{VA}-\mathrm{HC}$ \\
\hline Relational capital & $\mathrm{RC}$ & Marketing and selling expenses \\
\hline \multicolumn{3}{|l|}{ Control variables } \\
\hline Size & SIZE & Natural logarithm of total assets \\
\hline Leverage & LEV & Total debt / total assets \\
\hline Age & AGE & $\begin{array}{l}\text { Number of years that has passed since the day } \\
\text { of incorporation of the firm }\end{array}$ \\
\hline
\end{tabular}

\subsection{Research design}

To empirically test the hypotheses generated in Section 3, panel data analysis is utilized. The methodology has more variability, informativeness, and higher degrees of freedom as it combines time series and cross-sectional observations. The advantages of this methodology are mentioned as its ability to deal with heterogeneity, detect and quantify the effects that cannot be achieved by only times series and cross-sectional analysis (Baltagi, 2013). Additionally, the problem of multi-collinearity among the variables is reduced by the use of panel data analysis (Wooldridge, 2002).

Whereas models (1) - (2) are generated to evaluate the nexus between IC, which is respectively denoted by MVAIC and its components, and firm financial performance measured by ROA; models (3) - (4) are utilized to further analyze the influence of MVAIC and its components on firms' marketbased performance proxied by TOBINSQ. The functional representations of the models utilized can be seen below;

$$
\begin{gathered}
R O A_{i t}=\beta_{0}+\beta_{1} \text { VAIC }_{i t}+\beta_{2} S I Z E_{i t}+\beta_{3} L E V_{i t}+\beta_{4} P Y P E R F_{i t}+\epsilon_{i t} \\
R O E_{i t}=\beta_{0}+\beta_{1} V A I C_{i t}+\beta_{2} S I Z E_{i t}+\beta_{3} L E V_{i t}+\beta_{4} P Y P E R F_{i t}+\epsilon_{i t} \\
R O A_{i t}=\beta_{0}+\beta_{1} C E E_{i t}+\beta_{2} H C E_{i t}+\beta_{3} S C E_{i t}+\beta_{4} S I Z E_{i t}+\beta_{5} L E V_{i t}+\beta_{6} P Y P E R F_{i t}+\epsilon_{i t} \\
R O E_{i t}=\beta_{0}+\beta_{1} C E E_{i t}+\beta_{2} H C E_{i t}+\beta_{3} S C E_{i t}+\beta_{4} S I Z E_{i t}+\beta_{5} L E V_{i t}+\beta_{6} S G R O W T H_{i t}
\end{gathered}
$$


Numerous tests, the results of which can be seen in Appendix 1, are conducted to determine the estimator to be applied for each of the models. The results of the Likelihood-ratio (LR) test reveal the presence of either unit and/or time effects for all models, which proves that the models are not classical. Additional LR test results display that all models are one-way with unit effects. Depending on the outcomes of Hausman test, whereas models (1) and (2) are found to demonstrate fixed effects, models (3) and (4) are found to demonstrate random effects. In order to test the basic assumptions of panel data models, firstly, Modified Wald Test and Levene, Brown and Forsythe's Test are run for the fixed effects and random effects models, respectively, with the findings demonstrating the existence of heteroskedasticity. Subsequently, the results of Modified Bhargava et al. Durbin-Watson and BaltagiWu LBI Test demonstrate that all models are found to have autocorrelation. Finally, while BreushPagan LM, Pesaran and Frees tests are applied to fixed effects models to test for cross-sectional indepence; Pesaran and Frees tests are conducted to random effects models. All tests agree on the existence of cross-sectional independence. Accordingly, due to the presence of heteroskedasticity, autocorrelation, and cross-sectional independence; all models are regressed with Driscoll-Kraay standard errors (Tatoğlu, 2020, pp. 338-339).

\section{Findings}

The results of the models (1) - (4), which are generated to test the above stated hypothesis as to the influence of intellectual capital and its components on financial performance and firm value, are displayed on Table 3, below. Regarding models (1) and (3), intellectual capital, which is measured by MVAIC, is found to have no significant influence on both financial performance and value of Turkish listed manufacturing firms. This finding is contrary to the hypothesis generated but it is in line with the empirical evidence put forth by Buallay (2019) for only financial performance. Additionally, Buallay et al. (2019) also document this insignificant effect of intellectual capital on firm performance proxied by ROA for Islamic banks and on firm value measured by Tobin's Q for conventional banks in Gulf Cooperation Council economies.

Among the MVAIC components, CEE is found to be the only significant contributor to financial performance and firm value with $\beta=0.414, \mathrm{p}<1 \%$ and $\beta=2.299, \mathrm{p}<1 \%$, respectively for the selected companies in Turkey. This indicates that value created per dollar of capital employed boosts financial performance as in the studies of Nimtrakoon (2015), Restuti et al. (2018), Mohammad and Bujang (2019), Soetanto and Liem (2019). It has to be noted that the contribution of capital employed efficiency is much more strongly pronounced on firm value in comparison to firm profitability as indicated by the coefficients of the selected proxies. Therefore, while hypothesis 3) $\mathrm{H}_{1}$ and 7) $\mathrm{H}_{1}$ are accepted, all other remaining hypothesis as to the components are rejected. The positive influence of $\mathrm{CEE}$ on ROA is also revealed for Islamic and conventional banks in Gulf Cooperation Council economies by Buallay et al. (2019).

An evaluation of the results as to the control variables demonstrates that all selected variables are found to significantly influence ROA and TOBINSQ. As can be seen, firm size negatively affects both performance measures with this impact being more strongly pronounced for TOBINSQ in comparison to ROA, which is demonstrated by the larger coefficients in models (3) and (4). Furthermore, this negative relationship is also more significant for the models that utilize TOBINSQ as the dependent variable. The findings with respect to LEV indicate the existence of a negative relationship between the level of debt used to finance assets and selected performance measures. As displayed, the coefficients of this variable are higher for the models that evaluate the influence of IC and its components on firm value. Lastly, AGE is found to exert a positive impact on both performance measures meaning that as firms get older, they are demonstrating superior performance and value. 
Table 2

The results of the models (1)-(4)

\begin{tabular}{|c|c|c|c|c|}
\hline \multirow{3}{*}{$\begin{array}{l}\text { Method } \\
\text { Dependent Variable } \\
\text { Variables } \\
\end{array}$} & \multicolumn{2}{|c|}{ Fixed Effects } & \multicolumn{2}{|c|}{ Random Effects } \\
\hline & \multicolumn{2}{|c|}{ ROA } & \multicolumn{2}{|c|}{ TOBINSQ } \\
\hline & Model (1) & Model (2) & Model (3) & Model (4) \\
\hline \multirow[t]{2}{*}{ MVAIC } & -0.00116 & & 0.00225 & \\
\hline & $(0.00223)$ & & $(0.00635)$ & \\
\hline \multirow[t]{2}{*}{ HCE } & & -0.00027 & & -0.00460 \\
\hline & & $(0.00143)$ & & $(0.00372)$ \\
\hline \multirow[t]{2}{*}{ SCE } & & -0.05491 & & 0.05166 \\
\hline & & $(0.03768)$ & & $(0.10746)$ \\
\hline \multirow[t]{2}{*}{ RCE } & & -0.03236 & & 0.04691 \\
\hline & & $(0.02346)$ & & $(0.06761)$ \\
\hline \multirow[t]{2}{*}{ CEE } & & $0.41371 * * *$ & & $2.29952 * * *$ \\
\hline & & $(0.08719)$ & & $(0.53940)$ \\
\hline \multirow[t]{2}{*}{ SIZE } & $-0.10018 *$ & $-0.08622 *$ & $-0.25479 * * *$ & $-0.23686^{* * *}$ \\
\hline & $(0.04776)$ & $(0.04424)$ & $(0.06270)$ & $(0.06090)$ \\
\hline \multirow[t]{2}{*}{ LEV } & $-0.37114 * * *$ & $-.33252 * * *$ & $-0.89036 * * *$ & $-0.72941 * * *$ \\
\hline & (0.09827) & $(0.09797)$ & $(0.22046)$ & $(0.15935)$ \\
\hline \multirow[t]{2}{*}{ AGE } & $0.01706^{* *}$ & $0.01587 * *$ & $0.02088 * *$ & $0.02103 * *$ \\
\hline & $(0.00710)$ & $(0.00614)$ & $(0.00778)$ & $(0.00939)$ \\
\hline \multirow[t]{2}{*}{ constant } & $0.75992 *$ & 0.57622 & $4.09385 * * *$ & $3.35502 * * *$ \\
\hline & $(0.35658)$ & $(0.34704)$ & 0.92858 & $(0.91956)$ \\
\hline $\begin{array}{l}\text { Number of } \\
\text { observations }\end{array}$ & 825 & 825 & 825 & 825 \\
\hline Number of groups & 75 & 75 & 75 & 75 \\
\hline $\mathbf{F}$ & 10.42 & 56.85 & & \\
\hline Prob $>$ F & 0.0014 & 0.0000 & & \\
\hline Wald chi' ${ }^{2}$ & & & 38.82 & 170.81 \\
\hline Prob $>\mathbf{C h i}^{2}$ & & & 0.0000 & 0.0000 \\
\hline Within R-squared & 0.1425 & 0.1828 & & \\
\hline Overall R-squared & & & 0.1348 & 0.1919 \\
\hline Legend & $* p<0.10$ & $* * p<0.05$ & $* * * p<0.01$ & \\
\hline
\end{tabular}

\section{Conclusion}

This study is conducted to probe the possible influence of intellectual capital efficiency and its components on financial performance and value for manufacturing firms listed on BIST during the period between 2009 and 2019, inclusive. The findings for MVAIC utilized as the proxy for IC reveal no relation of this variable with the selected performance measures; namely ROA and TOBINSQ. In evaluating the individual impact of MVAIC components which are HCE, SCE, RCE, and CEE; it is observed for the Turkish manufacturing firms that CEE, short for physical capital, is found to be the only driving factor of both financial performance and firm value. Accordingly; human, structural, and relational capital are not found to exert a significant impact on selected measures of performance in Turkey for the observation period. Finally, an assessment of the results as to the control variables reveals that while firm size and leverage negatively influence both performance measures, firm age has positive impact in all models. 
In sum, the findings of this study are contrary to most of the prior empirical work focusing on data from different geographical regions showing that intellectual capital is an important contributor to companies' financial and market performance. The imperfect relationship found in this study may act as a signal for managers and professionals to investigate and explore the reasons behind this insignificant association. One explanation for this study's evidence can be dedicated to the relative lack of emphasis on and amount of IC related investments in Turkey. Therefore, these investments may turn out to be insufficient to have an influence on the selected proxies of performance. Furthermore, due to the potential that intellectual capital investments have a tendency to contribute to performance in the long-run, the insignificant finding as to MVAIC in this study can be adhered to the lack of using IC investments with time-lags.

As far as the literature review is concerned, studies utilizing MVAIC as an indicator of intellectual capital are limited for all countries, yet specifically for Turkey. This study is comprehensive in that it incorporates a large dataset with a long time-span; therefore, fills in this gap. Future studies can be performed on different industries to evaluate if intellectual capital has a tendency to generate a meaningful industry-wise effect on performance. Additionally, the models can be modified to employ time-lagged and different performance measures. Lastly, the study can be extended to provide results from different countries and regions to perform comparative analysis and reach relative evidence.

\section{Author statement}

\section{Research and publication ethics statement}

This study has been prepared in accordance with the ethical principles of scientific research and publication.

\section{Approval of Ethics Board}

Ethics Committee Approval is not required for this study.

\section{Conflict of interest}

There is no conflict of interest arising from the study for the authors or third parties.

\section{Declaration of support}

No support has been granted for this study

\section{References}

Andriessen, D. (2004). Making sense of intellectual capital: Designing a method for the valuation of intangibles. Burlington: Elsevier Butterworth-Heinemann.

Baltagi, B. H. (2013). Econometric analysis of panel data. England: John Wiley \& Sons.

Barney, J. (1991). Firm resources and sustained competitive advantage. Journal of Management, 17(1), 99-120. Download link: https://josephmahoney.web.illinois.edu/BA545_Fall\%202019/Barney\%20(1991).pdf

Bontis, N. (1998). Intellectual capital: an exploratory study that develops measures and models. Management Decision, 36(2), 63-76. doi:10.1108/00251749810204142

Bontis, N., Keow, W. C. C. and Richardson, S. (2000). Intellectual capital and business performance in Malaysian industries. Journal of Intellectual Capital, 1(1), 85-100. doi:10.1108/14691930010324188

Bontis, N., Janosevic, S. and Dzenopoljac, V. (2015). Intellectual capital in Serbia's hotel industry. International Journal of Contemporary Hospitality Management, 27, 1365-1384. doi:10.1108/IJCHM-12-2013-0541

Buallay, A. (2019). Intellectual capital and performance of Islamic and conventional banking: Empirical evidence from Gulf Cooperative Council Countries. Journal of Management Development, 38(7), 518-537. doi:10.1108/ JMD-01-2019-0020

Buallay, A., Cummings, R. and Hamdan, A. (2019). Intellectual capital efficiency and bank's performance: A comparative study after the global financial crisis. Pacific Accounting Review, 31(4), 672-694. doi:10.1108/ PAR-04-2019-0039

Clarke, M., Seng, D. and Whiting, R. H. (2011). Intellectual capital and firm performance in Australia. Journal of Intellectual Capital, 12(4), 505-530. doi:10.1108/14691931111181706 
Dzenopoljac, V., Yaacoub, C., Elkanj, N., and Bontis, N. (2017). Impact of intellectual capital on corporate performance: Evidence from the Arab region. Journal of Intellectual Capital, 18(4), 884-903. doi.org/10. 1108/JIC-01-2017-0014

Edvinsson, L. and Malone, M. (1997). Intellectual capital: Realizing your company's true value by finding its hidden Roots. New York: Harper Collins.

Firer, S., and Williams, S. M. (2003). Intellectual capital and traditional measures of corporate performance. Journal of Intellectual Capital, 4(3), 348 - 360. doi:10.1108/14691930310487806

Iazzolino, G. and Laise, D. (2013). Value added intellectual coefficient (VAIC): a methodological and critical review. Journal of Intellectual Capital, 14(4), 547-563. doi:10.1108/JIC-12-2012-0107

Johnson, W. (1999). Integrative taxonomy of intellectual capital: Measuring the stock and flow of intellectual capital components in the firm. International Journal of Technology Management, 18, 562-575. doi:10.1504/IJTM. 1999.002788

Joshi, M., Cahill, D., Sidhu, J. and Kansal, M. (2013). Intellectual capital and financial performance: an evaluation of the Australian financial sector. Journal of Intellectual Capital, 14(2), 264-285. doi:10.1108/14691931311323887

Maditinos, D., Chatzoudes, D., Tsairidis, C., and Theriou, G. (2011). The impact of intellectual capital on firms' market value and financial performance. Journal of Intellectual Capital, 12(1), 132-151. doi:10.1108/1469193111 1097944

Mohammad, H. S. and Bujang, I. (2019). Performance of Malaysian financial firms: An intellectual capital perspective using MVAIC model. Asian Economic and Financial Review, 9(7), 752-765. doi:10.18488/journal.aefr.2019. 97.752.765

Nazari, J. A. (2010). An investigation of the relationship between the Intellectual Capital components and firm's financial performance (Ph.D. Thesis, University of Calgary, Calgary). Download link: https://www. researchgate.net/publication/282134314_An_Investigation_of_the_Relationship_between_the_Intellectual_C apital_Components_and_Firm's_Financial_Performance

Nazari, J. A. and Herremans, I. M. (2007). Extended VAIC model: Measuring intellectual capital components. Journal of Intellectual Capital, 8(4), 595-609. doi:10.1108/14691930710830774

Nimtrakoon, S. (2015). The relationship between intellectual capital, firms' market value and financial performance: Empirical evidence from the ASEAN. Journal of Intellectual Capital, 16(3), 587-618. doi:10.1108/JIC-09-2014-0104

Organisation for Economic Co-operation and Development (2006). Policy brief: Creating value from intellectual assets. Download link: https://www.oecd.org/sti/inno/36701575.pdf

Petty, R. and Guthrie, J. (2000). Intellectual capital literature review: measurement, reporting and management. Journal of Intellectual Capital, 1(2), 155-176. doi:10.1108/14691930010348731

Pulic, A. (2004). Intellectual capital - does it create or destroy value? Measuring Business Excellence, 8, 62-8. doi: $10.1108 / 13683040410524757$

Pulic, A. (2000). VAICTM an accounting tool for IC management. International Journal of Technology Management, 20(5), 702-714. doi:10.1504/IJTM.2000.002891

Restuti, M. D., Diyanty, V. and Shauki E. R. (2018). Intellectual capital and firm performance: Applying a modified nalue-added coefficient. Advances in Economics, Business and Management Research, 89, 114123. doi:10.2991/apbec-18.2019.16

Roos, G. and Roos, J. (1997). Measuring your company's intellectual performance. Long Range Planning, 30(3), 413-426. doi:10.1016/S0024-6301(97)90260-0

Soetanto, T. and Liem, P. F. (2019). Intellectual capital in Indonesia: dynamic panel approach. Journal of Asia Business Studies, 13(2), 240-262. doi:10.1108/JABS-02-2018-0059

Stahle, P., Stahle, S. and Aho, S. (2011), Value added intellectual coefficient (VAIC): A critical analysis. Journal of Intellectual Capital, 12(4), 531-551. doi:10.1108/14691931111181715

Stewart, T. A. (1997). Intellectual capital: The new wealth of organizations. New York: Currency Doubleday.

Sveiby, K. E. (1997). The new organizational wealth: Managing and measuring knowledge-based assets. San Francisco: Berrett-Koehler. 
Tatoğlu, F. Y. (2020). Panel veri ekonometrisi stata uygulamalı. İstanbul: Beta Yayınları.

Tiwari, R. (2020). Nexus between intellectual capital and profitability with interaction effects: panel data evidence from the Indian healthcare industry. Journal of Intellectual Capital, Vol. ahead-of-print. doi:10.1108/JIC-05-2020-0137

Tran, D. B. and Vo, D. H. (2018). Should bankers be concerned with Intellectual capital? A study of the Thai banking sector. Journal of Intellectual Capital, 19(5), 897-914. doi:10.1108/JIC-12-2017-0185

Ulum, I., Kharismawati, N. and Syam, D. (2017). Modified value-added intellectual coefficient (MVAIC) and traditional financial performance of Indonesian biggest companies. International Journal of Learning and Intellectual Capital, 14(3), 207-219. doi:10.1504/IJLIC.2017.086390

Vishnu, S. and Gupta, V. K. (2014). Intellectual capital and performance of pharmaceutical firms in India. Journal of Intellectual Capital, 15(1), 83-99. doi:10.1108/JIC-04-2013-0049

Wernerfelt, B. (1984). A resource-based view of the firm. Strategic Management Journal, 5, 171-180. Download link: http://web.mit.edu/bwerner/www/papers/AResource-BasedViewoftheFirm.pdf

Wooldridge, J. M. (2002). Econometric analysis of cross section and panel data. United States: The MIT Press.

$\mathrm{Xu}$, J. and Li, J. (2019). The impact of intellectual capital on SMEs' performance in China Empirical evidence from non-high-tech vs. high-tech SMEs. Journal of Intellectual Capital, 20(4), 488-509. doi:10.1108/JIC-042018-0074

$\mathrm{Xu}, \mathrm{J}$. and Li, J. (2020). The interrelationship between intellectual capital and firm performance: evidence from China's manufacturing sector. Journal of Intellectual Capital, Vol: ahead-of-print, doi:10.1108/JIC-08-20190189

$\mathrm{Xu}$, J. and Wang, B. (2019). Intellectual capital performance of the textile industry in emerging markets: A comparison with China and South Korea. Sustainability, 11(8), 1-16. doi:10.3390/su11082354

Yao, H., Haris, M., Tariq, G., Javaid, H. M. and Khan, M. A. S. (2019). Intellectual capital, profitability, and productivity: Evidence from Pakistani financial institutions. Sustainability, 11, 1-30. doi:10.3390/su111438 42

Y1lmaz, İ. and Acar, G. (2018). The effects of intellectual capital on financial performance and market value: Evidence from Turkey. Eurasian Journal of Business and Economics, 11(21), 117-133. doi:10.17015/ejbe.2018.021.07

Zeghal, D. and Maaloul, A. (2010) Analyzing value added as an indicator of intellectual capital and its consequences on company performance. Journal of Intellectual Capital, 11(1), 39-60. doi:10.1108/14691931011013325 


\section{Appendix 1}

The Results of the Tests to Determine the Estimators for the Models

\begin{tabular}{|c|c|c|c|c|}
\hline & Model (1) & Model (2) & Model (3) & Model (4) \\
\hline \multicolumn{5}{|c|}{ Testing for Unit and/or Time Effects with Likelihood Ratio (LR) Test } \\
\hline LR test for Unit and Time Effects & Prob $>$ chi $2=0.0000$ & Prob $>$ chi $2=0.0000$ & Prob $>$ chi $2=0.0000$ & Prob $>$ chi $2=0.0000$ \\
\hline LR test for Unit Effects & Prob $>=$ chibar $2=0.0000$ & Prob $>=$ chibar $2=0.0000$ & Prob $>=$ chibar $2=0.0000$ & Prob $>=$ chibar $2=0.0000$ \\
\hline LR test for Time Effects & Prob $>=$ chibar $2=1.0000$ & Prob $>=$ chibar $2=1.0000$ & Prob $>=$ chibar $2=0.1625$ & Prob $>=$ chibar $2=0.0565$ \\
\hline \multicolumn{5}{|l|}{$\begin{array}{l}\text { Testing for Fixed and Random } \\
\text { Effects }\end{array}$} \\
\hline Hausman Test Results & Prob $>$ chi $2=0.0000$ & Prob $>$ chi $2=0.0000$ & Prob $>$ chi $2=0.5936$ & Prob $>$ chi $2=0.5513$ \\
\hline \multicolumn{5}{|l|}{ Testing for Heteroskedasticity } \\
\hline Modified Wald Test & Prob $>$ chi $2=0.0000$ & Prob $>$ chi $2=0.0000$ & & \\
\hline \multicolumn{5}{|l|}{$\begin{array}{l}\text { Levene, Brown and Forsythe's } \\
\text { Test }\end{array}$} \\
\hline $\mathrm{W} 0=9.4158440 \mathrm{df}(74,750)$ & & & $\operatorname{Pr}>F=0.0000$ & \\
\hline $\mathrm{W} 50=6.5985842 \mathrm{df}(74,750)$ & & & $\operatorname{Pr}>\mathrm{F}=0.0000$ & \\
\hline $\mathrm{W} 10=8.2646451 \mathrm{df}(74,750)$ & & & $\operatorname{Pr}>F=0.0000$ & \\
\hline $\mathrm{W} 0=9.1582272 \operatorname{df}(74,750)$ & & & & $\operatorname{Pr}>\mathrm{F}=0.0000$ \\
\hline $\mathrm{W} 50=6.3578320 \mathrm{df}(74,750)$ & & & & $\operatorname{Pr}>\mathrm{F}=0.0000$ \\
\hline $\mathrm{W} 10=8.0426421 \quad \mathrm{df}(74,750)$ & & & & $\operatorname{Pr}>F=0.0000$ \\
\hline \multicolumn{5}{|l|}{ Testing for Autocorrelation } \\
\hline $\begin{array}{l}\text { Modified Bhargava et al. Durbin- } \\
\text { Watson }\end{array}$ & .75439478 & .80726514 & 1,6469291 & 1,6730953 \\
\hline Baltagi-Wu LBI & .94146864 & .99446081 & 1,8646796 & 1,8755397 \\
\hline \multicolumn{5}{|c|}{ Testing for Cross Sectional Independence } \\
\hline Breush-Pagan LM Test & $\operatorname{Pr}=0.0000$ & $\operatorname{Pr}=0.0000$ & & \\
\hline Pesaran's Test & $\operatorname{Pr}=0.0000$ & $\operatorname{Pr}=0.0000$ & $\operatorname{Pr}=0.0000$ & $\operatorname{Pr}=0.0000$ \\
\hline Frees' Test & 8.824 & 7.159 & 6.786 & 6.018 \\
\hline \multicolumn{5}{|l|}{$\begin{array}{l}\text { Critical values from Frees' Q } \\
\text { distribution }\end{array}$} \\
\hline alpha $=0.10$ & .2333 & .2333 & .2333 & .2333 \\
\hline alpha $=0.05$ & .3103 & .3103 & .3103 & .3103 \\
\hline alpha $=0.01$ & .4649 & .4649 & .4649 & .4649 \\
\hline
\end{tabular}

